\title{
APLIKASI MOTIF BATIK PADA PAKAIAN APD
}

\author{
Aan Sudarwanto ${ }^{1}$ \\ ${ }^{1}$ Prodi Desain Mode Batik ISI Surakarta \\ Email: aansudarwanto@gmail.com
}

\begin{abstract}
ABSTRAK
Artikel ini merupakan hasil penelitian terapan dengan pendekatan eksperimentasi. Fokus penelitian pada penerapan motif ke pakaian APD, agar memberikan kesan familier dan indah. Penelitian ini bertujuan untuk menjawab permasalahan tentang aplikasi pengembangan motif batik. Bahwa motif batik tidak hanya digunakan dalam busana formal saja namun dapat masuk ke semua ranah termasuk ke dalam pakaian $A P D$. Tujuan kedua adalah untuk membuat model (penerapan motif pada pakaian APD) sehingga dapat digunakan pada industri fasyen. Penelitian diharapkan memberi kontribusi terhadap munculnya inovasi baru (pakaian APD bermotif). Metode yang dilakukan menggunakan eksperimentasu untuk menghasilkan model. Dimulai dengan mencari kemungkinan pemanfaatan menggunakan rancangan dari program komputer grafis. Dengan sasaran dibatasi pada masalah pengembangan motif dan aplikasinya pada pakaian APD. Objek penelitiannya adalah pakaian APD. Adapun langkah-langkah perancangan untuk menghasilkan model yang berupa prototipe diawali dengan melakukan riset emik dan etik kemudian melakukan eksperimen melalui perenungan dengan mereka-reka pengembangan motif yang bersumber dari motif batik untuk disesuaikan dengan pakaian APD dengan mencari kesesuaiannya yang berdasar kaidah estetika dan dilanjutkan dengan pembentukan. Hasil penelitian ini berupa model prototipe pakaian $A P D$ bermotif dengan beberapa variasi yang dihasilkan dari strategi keteknikan dalam pengerjaannya.
\end{abstract}

Kata kunci: pakaian, APD, motif, batik

\section{PENDAHULUAN}

\section{Latar Belakang}

Alat Pelindung Diri (APD) menjadi pelengkapan kesehatan yang paling dibutuhkan saat pandemi virus Corona atau disebut juga dengan virus Covid-19 sekarang ini. APD merupakan peralatan yang akan melindungi pengguna terhadap risiko kesehatan atau keselamatan di tempat kerja, terutama bagi mereka yang bekerja di tempat berisiko tinggi mengalami kecelakaan, cedera, atau tertular penyakit, seperti di area konstruksi atau di fasilitas kesehatan. Kepala Pusat Data Informasi dan Komunikasi Kebencanaan BNPB Agus Wibowo menyampaikan, dilihat dari lokasi dan cakupan, rekomendasi standar alat pelindung diri (APD) sangat penting diperuntukkan untuk ruang prosedur dan tindakan operasi pada pasien dengan kecurigaan atau sudah terkonfirmasi COVID-19 (Media on line liputan6. com link : https://www. liputan6. com/health/ $\mathrm{read} / 4218517 /$ syarat-standar-alat-pelindungdiri-saat-tangani-corona-covid-19). Pada sisi lain, dengan semakin merebaknya wabah virus corona di berbagai kota di Indonesia maka perluasan penggunaan alat pelindung diri (APD) ini digunakan semakin meluas. Penggunaannya tidak saja oleh paramedis tetapi telah berkembang ke berbagai profesi dikalangan masyarakat. Salah satunya di lingkungan kepolisian, hal ini disampaikan oleh Kabagpenum Divisi Humas Mabes Polri Kombes Pol Asep Adi Saputra menyampaikan bahwa anggota Polri diharuskan menggunakan alat pelindung diri atau APD selama bertugas di tengah pandemi virus corona atau covid-19. Lebih lanjut dijelaskan bahwa beberapa tugas yang anggota Polri diharuskan mengenakkan APD seperti patroli, menyambangi masyarakat, dan memberi pertolongan bagi masyarakat yang mengalami kecelakaan lalu lintas (Media on line Ayobandung.com link: https://www. 
ayobandung.com/read/2020/04/09/85457/polisi-wajib-pakai-apd-selama-pandemi-corona). Bahkan lebih jauh lagi selama merebaknya wabah virus corona ini kepolisian diwajibkan menggunakan APD yang dijelaskan oleh Asep sebagai berikut; "Secara umum kami sampaikan juga bahwa penggunaan alat pelindung diri bagi Kepolisian Negara Republik Indonesia dalam tugas sehari-hari adalah sebuah keharusan. Baik dalam tugas rutin, tugas yang sifatnya mobilitas pelayanan kepada masyarakat," kata Asep saat jumpa pers seperti dikutip dari siaran langsung YouTube BNPB (Media on line Ayobandung. com).

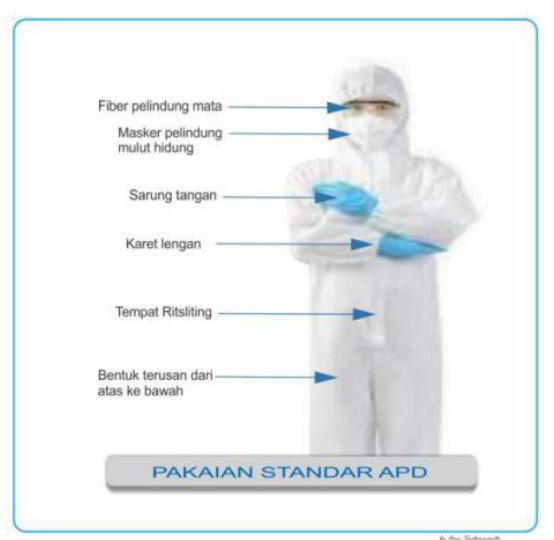

Gambar: pakaian APD yang sering digunakan dan berkembang di masyarakat sebagai alat pelindung diri dengan model terusan polos dan berwarna putih. Kesan kurang familier yang muncul ketika menggunakan pakaian ini terasa mengerikan dan menyebabkan semakin takut pada masyarakat di tengah-tengah horor wabah virus corona.

Pentingnya APD disaat wabah seperti sekarang ini, menjadikan APD sebagai pakaian pelindung diri yang paling dicari oleh berbagai profesi maupun berbagai lapisan yang ada di masyarakat. APD ini juga sekaligus menjadikan kesan momok yang menakutkan di tengah masyarakat yang memang trauma dan ketakutan dengan pendemi wabah virus corona. APD yang bentuknya yang hazmat ${ }^{1}$ dan rata-rata ber-

$1 \quad$ Hazmat merupakan singkatan dari hazardous materials atau bahan-bahan berbahaya, atau dikenal juga dengan nama pakaian dekontaminasi, yakni warna putih dan terkadang warna polos lain memberi kesan kurang familier, dan menjadi momok baru di tengah-tengan masyarakat. Apa lagi kalau terkadang beberapa orang terlalu over berlebihan dengan dipasang alat bantu pernapasan bukan masker yang berbentuk topeng penutup wajah. Dengan melihat fenomena tersebut maka diperlukan inovasi alat APD yang secara fungsi sebagai alat pelindung diri namun juga secara estetika juga menimbulkan kesan indah, familier dan tidak menimbulkan kesan menakutkan. Salah satu gagasan agar lebih terkesan familier yakni dengan menerapkan motif batik pada pakaian APD. Motif batik merupakan imajinasi yang dapat menggambarkan cita-cita atau pengharapan (Sudarwanto., 2012). Diharapkan dengan memunculkan varian pakaian APD yang memanfaatkan motif batik akan dapat memunculkan pengharapan, meringankan sekaligus menghilangkan kesan horor.

Pengamatan awal di lapangan yang dihubungkan dengan penelitian ini, dapat diketahui tentang bagaimana bentuk pakaian APD dan realitanya yang berkembang sekarang ini adalah sebagai berikut:

a. Ternyata tidak ada atau bisa dikatakan tidak ditemukan pakaian APD yang menggunakan motif baik sebagai ornamen utama maupun sebagai ornamen pendukung yang memberikan kesan lebih estetis, familier dan tidak menakutkan. Dengan mempopulerkan motif sebagai ornamen hias pada pakaian APD, maka akan memberikan kesan artistik dan familier sehingga, setidaknya dapat meringankan pasien penderita virus corona maupun dapat menenangkan masyarakat terhadap merebahnya wabah virus corona.

b. Tidak ditemui motif yang dirancang khusus untuk pakaian APD sehingga bisa dimulai inovasi dengan memanfaatkan potensi yang bersumber dari budaya local nusantara untuk dapat bersaing dengan

perlengkapan perlindungan diri yang terdiri dari bahan yang impermeabel dan digunakan untuk proteksi melawan sesuatu berbahaya 
komunitas global sebagai penciri khuhus yang tidak dimiliki bangsa atau komunitas lain. Pada tahap ini diperlukan desainer khusus untuk memunculkan motif baru yang dapat digunakan sebagai penghias pakaian APD.

c. Pada era sekarang dimana hampir semua negara mengalami wabah pendemi virus corona, sehingga diperlukan inovasi dan kreasi yang mampu menjawab perubahan dan tatangan zaman.

Berpijak dari permasalahan tersebut maka perlu adanya pemanfaatan dan pengembangan model bentuk pakaian APD yang bersumber dari budaya nusantara khususnya batik yang mampu bersaing mengikuti perkembangan zaman untuk menggerakkan sektor ekonomi masyarakat.

\section{Tujuan}

Pengembangan model ini diharapkan mampu meningkatkan pemahaman variasi produk sehingga secara tidak langsung akan meningkatkan nilai ekonomi. Hal tersebut menjadi target untuk mencapai tujuan yaitu

a. Untuk mengembangan motif sebagai penghias APD sehingga secara tidak langsung akan meningkatkan variasai dan nilai jual sekaligus memberi banyak alternatif pilihan.

b. Penelitian diharapkan memberi kontribusi terhadap munculnya inovasi baru yang berupa model pakaian APD yang bermotif.

\section{Metode}

Penelitian yang dilakukan menggunakan metode eksperimental. Pengembangan model pakaian APD dimulai dengan mencari kemungkinan pengembangan motif menggunakan rancangan dari program komputer grafis, dengan membatasi objek pada pengembangan motif batik. Eksperimental dilakukan bertujuan mengungkap sebab-akibat antar dua variabel atau lebih; lewat percobaan-percobaan dengan memanipulasi/ mengubah-ubah nilai variabel untuk mengamati akibatnya pada variabel, dalam suatu seting yang terkendali (bebas dari campur tangan variabel di luar fokus penelitian). Pada dasarnya model penelitian ini lebih cocok untuk meneliti karakter benda. Sedangkan untuk menghasilkan alternatif yang tepat, penelitian ini juga memerlukan pemanfaatan metode pemodelan. Dasar pemikiran penelitian Pemodelan dapat dilakukan terhadap tiruan obyek, sehingga memudahkan jalannya penelitian. Metode Pemodelan yaitu rancangan untuk acuan pembuatan prototipe.

\section{PEMBAHASAN}

Pembahasan motif batik pada pakaian APD ini, diawali dengan membahas tentang persepsi terkait dengan APD yang dihasilkan. Presepsi merupakan rangkaian proses rumit yang diperoleh dari intepretasi informasi indrawi. Intepretasi ini memungkinkan untuk menyerap lingkungan secara bermakna halhal yang kita indra. Dari sini maka persepsi dapat didefinisikan intepretasi hal-hal yang kita indra (Sudarwanto, 2019). Lebih lanjut bisa dikatakan bahwa persepsi merupakan seperangkat proses yang dengannya kita mengenali, mengorganisasikan dan memahami tangkapan indrawi yang kita terima dari stimuli lingkungan. Berpijak dari sini maka pembuatan pakaian APD dengan tujuan agar memberikan persepsi kesan familier maka tidak salah jika digunakan motif batik sebagai serapan indrawi yang telah familier dan dikenal di masyarakat. Motif batik berfungsi sebagai pemberi interpertasi indrawi memberikan kesan keindahan dan memberikan kesan familier. Pada penelitian ini pakaian APD dibuat dengan standar kesehatan yang ada namun juga dibuat dengan memperhatikan aspek keindahan dengan memberikan motif pada pakaian APD tersebut. Pemberian motif sebagai hiasan pakaian APD dimaksudkan akan memberikan persepsi positif pada pemakainya sekaligus menghilangkan kesan menakutkan. Langkah-langkah yang dilakukan dalam mengembangkan motif ini ditempuh dalam beberapa metode antara lain :

a.Membuat motif baru yang berfungsi memberikan stimulan dan semangat dalam bekerja menghadapi wabah covid-19. 
b. Menggunakan motif yang sudah ada, hal ini karena motif yang sudah ada sudah dikenal, disamping itu jaga dari sisi pembiayaan akan lebih ekonomis.

c. Menggunkan motif batik asli yang dikobinasikan pada pakaian APD. Hal ini disebabkan penggunaan material APD harus sesuai standar kesehatan, yaitu salah satunya tidak menyerap droplet.

Tiga hal tersebut, menjadi pijakan dalam penerapan motif batik pada pakaian APD sehingga memunculkan kesan familier. Perlu dijelaskan bahwa motif batik yang dimaksud di sini bukan berarti batik sebagai teknik pembuatan kain dengan teknik malam rintang, akan tetapi cenderung lebih luas. Karena teknik penerapan motif batik dapat dilakukan dengan berbagai ragam keteknikan. Diantaranya dicetak digital, cetak printing sablon, dilukis hingga dipahat. Pada penelitian ini dilakukan dengan 3 keteknikan yaitu cetak printing sablon, cetak digital dan motif pada kain batik yang dikombinasikan dengan material APD. Sebagai pertimbangan dalam pemilihan keteknikan tersebut diantantaranya jenis dan karekter material APD yang sesuai standar yang ada yakni sebagai berikut (Ardyananta dkk, 2020) :

a.Secara umum, APD bekerja sebagai pelindung diri bagi penggunanya dengan cara menghambat transportasi Hazmat yang lewat melalui pori APD dari lingkungan terhadap pengguna. Perangkat APD harus memiliki kemampuan menyaring atau tidak dapat ditembus oleh material berbahaya. Penyaringan dapat dilakukan jika ukuran partikel material berbahaya lebih besar dari ukuran lubang pori pada material APD. Absorpsi Hazmat juga dapat dicegah dengan penggunaan material APD dengan material yang tidak dapat terbasahi oleh Hazmat atau memberikan lapisan tipis pada APD. Lapisan yang diberikan dapat berupa lapisan semi berpori (semipermeabel), pori selektif (selective permeable), atau materi tidak berpori (completely impermeable) tergantung jenis Hazmat yang akan ditapis.

b. Sifat permeabilitas material yang tidak terbasahi oleh air atau cairan disebut hidrofobik. Sifat hidrofobik ini dapat diuji dengan uji kebasahan. Dalam aplikasi kehidupan sehari-hari, sifat hidrofobik dikenal dengan istilah anti air, water resistant, water repellent, dan waterproof .

c. Standar WHO, memiliki standar spesifik mengenai APD yang tertuang dalam WHO-Preferred Product Characteristics for PPE, 2017 untuk menangani virus pandemi. Spesifikasi tersebut termasuk resistensi terhadap penetrasi cairan dan virus (ISO 16603:2004; AATCC 42\&47; ASTM F1670-1671), ketahanan terhadap disinfektan (ASTM 5034; ISO 13934-1) serta sinar infrared (ASTM F 2668). Mengacu pada standar di atas, secara umum spesifikasi APD harus memenuhi persyaratan mampu mencegah atau menapis Hazmat, kuat tangguh dan nyaman (breathable).

d. Standar EU. Standar EU tentang regulasi PPE 2016/425 menyatakan kemampuan perlindungan APD dibagi menjadi 3 tingkatan. Kategori 1 APD sederhana untuk perlindungan tingkat dasar. Kategori kedua adalah yang tidak termasuk kategori 1 dan 2. Kategori 3 adalah APD yang melindungi pengguna atau pemakainya dari bahaya yang berpotensi fatal, kerusakan kesehatan yang serius, tidak dapat diubah atau resiko tinggi.

e.Standar SNI. Standar DIN EN ISO 13688 tentang persyaratan umum pakaian pelindung diri harus mencantumkan tingkat ergonomi, batasan, masa berlaku, ukuran, kompatibilitas dan informasi yang dibagi 5 tipe perlindungan sesuai dengan tingkatannya. Tingkat perlindungan tertinggi adalah jika dapat mencegah dan menapis gas, lebih rendah lagi tipe 3 untuk mencegah dan menapis cairan dan pengujian dilakukan dengan jet test (EN 14605), selanjutnya tipe 4 menapis cairan dalam bentuk semprotan, diuji dengan spray test (EN 14605) dan kemampuan terendah adalah tipe 5/6 untuk menapis partikel padatan, semprotan terbatas atau cairan dalam bentuk kabut (ISO 13982-1 atau EN 13034) 
Mengacu pada standar tersebut di atas maka dalam menentukan material yang paling memungkinkan untuk ditambahkan ornamen hias maka dipilih material Cotton Spundbond $75 \mathrm{gsm}$. Material ini direkomendasikan pada Spundbond yang berlapis Polypropylene PE sehingga waterproof.

\section{Pembuatan Motif}

Proses pembuatan motif dilakukan melalui beberapa tahapan agar diperoleh motif yang paling sesuai dengan pakaian APD. Yakni tahap observasi, tahap perekaan motif dan tahap penentuan motif. Beberapa indikator digunakan untuk pijakan penentuan motif. Diantaranya adalah sebagai berikut.

a. Adanya kesesuaian tema dengan isu kekinian yang diangkat dan berkembang dimasyarakat pada masa ini

b. Adanya kaidah estitika dalam penggarapan desainnya

c. Adanya kesederhanaan motif dan kemudahan dalam aplikasinya pada pakaian APD

d. Adanya kemudahan dalam teknik penggarapannya ketika di aplikasikan pada pakaian APD.

Adapun dalam proses pembuatnnya menghasilkan beberapa alternatif desain yang akan digunakan. Desain-desain itu antara lain sebagai berikut.

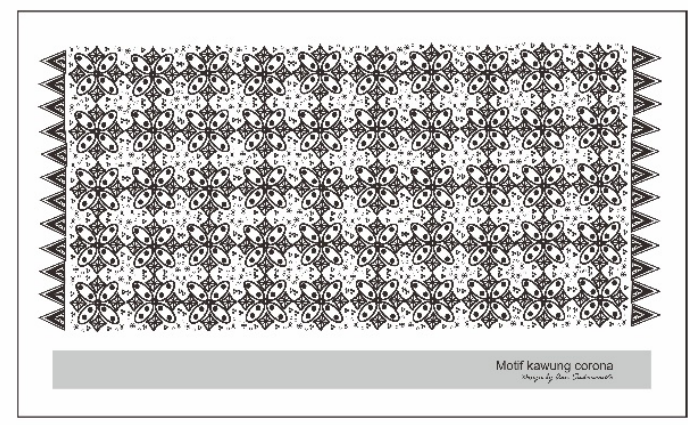

Gambar hasil desain 1, merupakan motif dengan judul "Kawung Corona", motif yang mengisaratkan tentang perpaduan bentuk klasik dengan isu kekinian yakni virus corona (Sudarwanto, 2020)

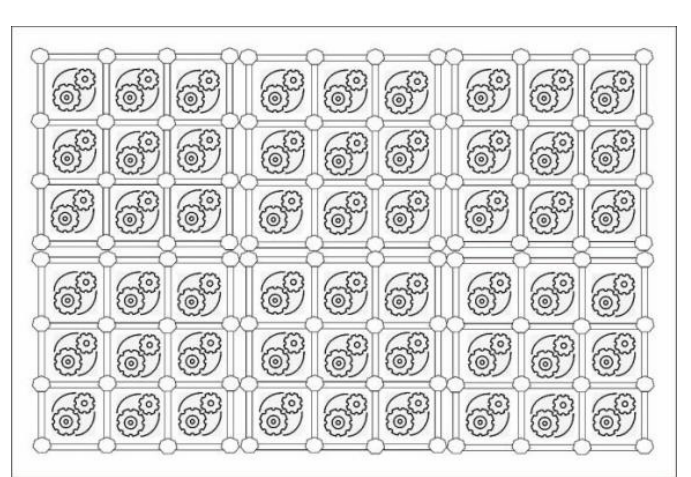

Gambar desain 2, berjudul "Roda Kehidupan" merupakan gambaran bahwa kehidupan terus berputar terkadang harus siap menghadapi cobaan seperti wabah covid-19 (Sudarwanto, 2020).

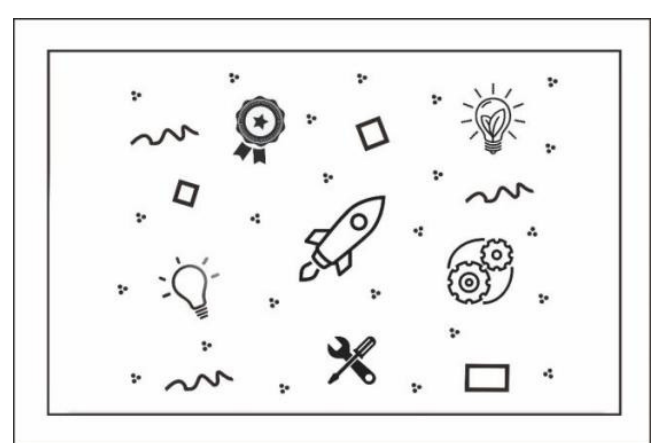

Gambar desain 3 Judul "Kerja Cerdas" merupakan gambaran kebutuhan manusia disaat menghadapi wabah covid-19. Tetap beraktifitas namun dengan cara cara baru yang lebih cerdas, dimulai dari perencanaan, action, iktiyar, doa, tumbuh berkembang dan mencapai hasil yang diinginkan (Sudarwanto, 2020).

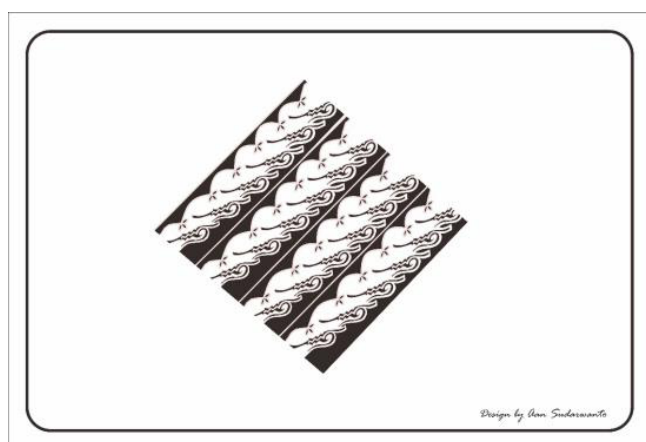

Gambar desain alternatif 4 Judul "Perang-perangan" merupakan gambaran panik dan bingung disaat menghadapi wabah Covid-19 (Sudarwanto, 2020)

Dari keempat desain alternatif yang telah dihasilkan tersebut kemudian dipilah dua 
desain, yakni desain 3 dan desain 4 untuk diaplikasikan pada pakaian APD. Pemilihan ini didasari karena adanya beberapa pertimbangan antara lain, adanya beberapa variasi motif utama pada desain alternatif 3 dan alternatif 4 , selain itu juga latar belakang tema yang sangat cocok dengan kondisi tema besar penelitian ini. Selain itu juga simbol-simbol iconik yang terdapat pada desain tersebut menunjukkan situasi kekinian sehingga diharapkan mudah dipahami oleh masyarakat.

\section{APD Bermotif}

\section{a. Variasi APD}

Penerapan motif pada pakaian APD agar muncul kesan familier pada penelitian ini, diambil beberpa tindakan atau metode untuk memunculkan variasi, yakni :

a) Membuat batik pada kain catton primisima kemudian ditempelkan pada material APD sebagai variasi baru. Kemudian, agar sesuai dengan standar APD pada bagian batik tersebut diberi plastik mika sehingga menjadi waterproof.

b) Menempatkan motif langsung pada material APD, dengan teknik printing sablon. Teknik printing dipilih karena yang paling memungkinkan dilakukan pada material APD yang waterproof, disamping biaya juga lebih terjangkau. Penerapan motif dengan cara dibatik pada material APD dipandang tidak memungkinkan, baik dari segi biaya maupun efisiensi waktu kepraktisannya.

c) Pemilihan material Spundbond yang telah ada motif pabrikannya sebagai material APD. Pemilihan material jenis ini tetap memperhatikan standar APD yang salah satunya waterproof.

\section{b. Teknik Pembuatan}

Proses pembuatan pakaian APD dapat dikelompokkan menjadi beberapa tahapan antara lain: perancangan/desain, pemotongan, perakitan dan finishing. Berikut uraian penjelasan eksperimentasi pembuatan pakaian APD untuk menhasilkan prototype pakaian APD bermotif batik.

a. Desain / Perancangan

Pada tahap rancangan APD, seperti yang telah dijelaskan sebelumnya diawali dari penentuan desain motif. Kemudian dilakukan pembuatan pola pakaian APD, yang terdiri dari 5 potongan yaitu :

- Pola bagian kepala

- Pola bagian badan belakang

- Pola bagian badan depan

- Pola bagian kaki belakang

- Pola bagian lengan / tangan

Kelima potongan ini murupakan pola pakaian APD model wearpack. Model ini bentuknya terusan dari mulai badan hingga kaki. Untuk lebih jelasnya dapat dilihat pada gambar pecah pola berikut ini.

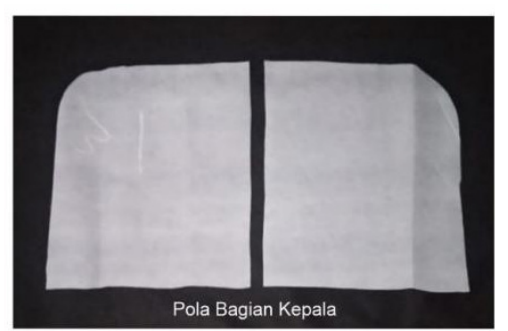

Gambar potongan pola untuk bagian penutup kepala pakaian APD (Sudarwanto, 2020).

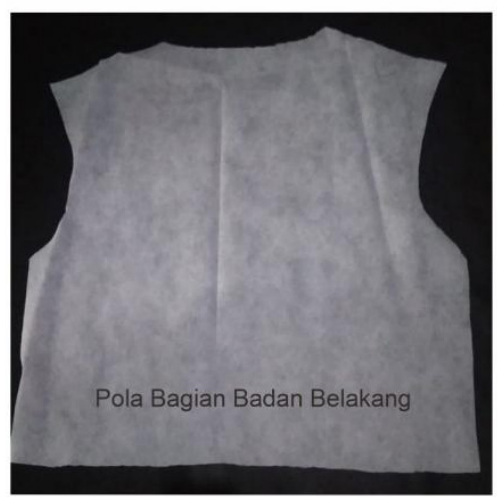

Gambar potongan pola untuk bagian badan belakang pakaian APD. Pada bagian ini dibuat tidak terusan sampai kaki karena sambungan antara bagan badan belakang dan kaki belakang diberi karet elastik agar enak dipakai (Sudarwanto, 2020) 


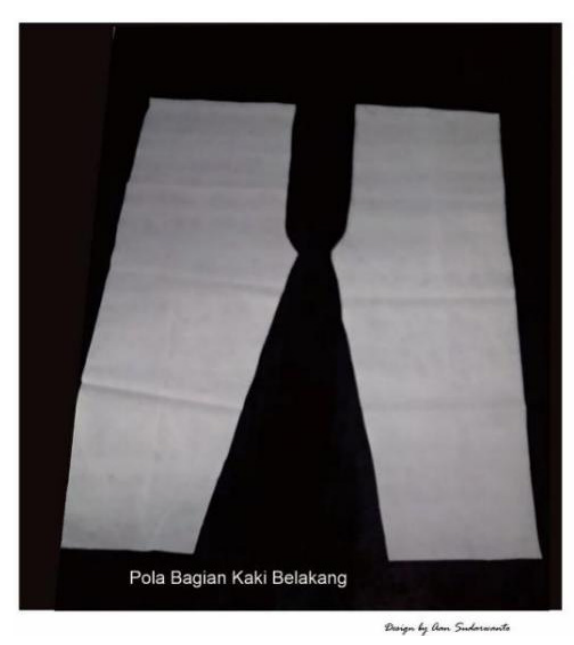

Gambar potongan pola untuk bagian kaki belakang pakaian APD. Pada bagian ini dibuat menyambung dengan badan belakang. Sambungan antara bagan badan belakang dan kaki belakang nantinya ditambah karet elastik agar enak dipakai (Sudarwanto, 2020).

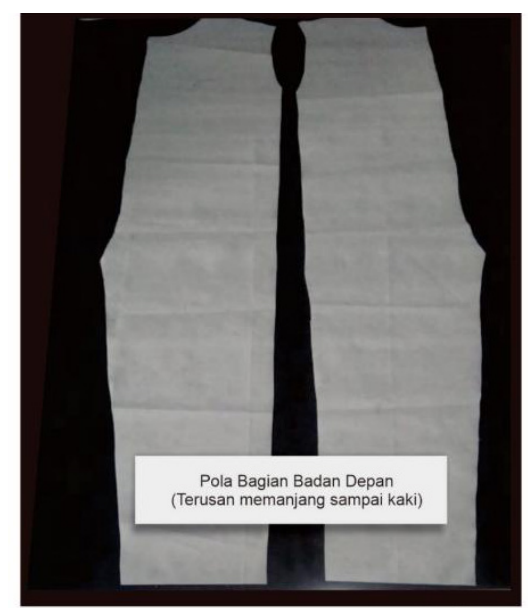

Gambar potongan pola untuk bagian badan depan pakaian APD. Pada bagian ini dibuat terusan sampai kaki (Sudarwanto, 2020).

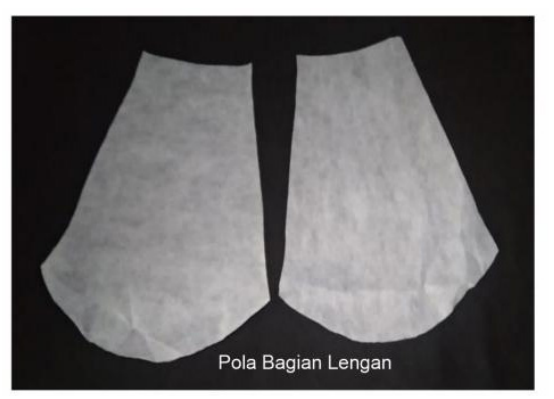

Gambar potongan pola untuk bagian lengan / tangan pakaian APD (Sudarwanto, 2020).

\section{b. Pemotongan}

Pemotongan dilakukan dengan memperhatikan bentuk motif terutama pada prototype 1 dan 3 agar memperoleh bentuk yang baik dan proporsional. Hal-hal yang harus diperhatikan antara lain

- Bentuk motif jangan samapai terbalik agar enak dipandang ketika pakaian APD sudah jadi.

- Penggalan potongan motif dibuat sanggit atau bersambung sehingga akan tambpak rapi jika dipakai.

Untuk prototype 2 penempatan batik sebagai variasi perlu memperhatikan beberpa kaidah-kaidah estetika/ keindahan sehingga motif akan tampak dominan namun sekaligus memperindah pakaian APD. Beberpa kaidah yang perlu diperhatikan antara lain balance, dominasi / pusat perhatian dan proporsi.

\section{c. Perakitan}

Perakitan dilakukan dengan teknik jahit, hal ini menyesuaikan dari material yang digunakan. Berbeda jika menggunakan material poliester dan pve yaitu dengan dipress panas. Pada proses penjahitan ini agar tidak terdapat celah yang memungkinkan bisa masuknya kuman penyakit pada pakaian APD ini, maka digunakan perekat list jahit pada setiap sambungannya. Beberapa perlakuan yang ditambahkan dalam perkitan ini antara lain, pemberian resleting pada bagian badan depan. Selain itu juga penambahan karet dibeberpa titik penting antarlain dapat dilihat dalam tabel berikut. 


\begin{tabular}{|l|l|l|}
\hline No & $\begin{array}{l}\text { Penempa- } \\
\text { tan karet }\end{array}$ & \multicolumn{1}{|c|}{ Fungsi } \\
\hline 1 & $\begin{array}{l}\text { Bagian } \\
\text { kedua } \\
\text { pergelan- } \\
\text { gan tangan }\end{array}$ & $\begin{array}{l}\text { Agar tidak tersingkap atau } \\
\text { tertarik ke belakang ketika } \\
\text { pakaian APD dikenakan }\end{array}$ \\
\hline 2 & $\begin{array}{l}\text { Bagian } \\
\text { bawah } \\
\text { kedua kaki }\end{array}$ & $\begin{array}{l}\text { Memperkokok sehingga } \\
\text { tidak tertarik ke atas ketika } \\
\text { pakaian APD dikenakan }\end{array}$ \\
\hline 3 & $\begin{array}{l}\text { Bagian } \\
\text { ujung tutup } \\
\text { kepala }\end{array}$ & $\begin{array}{l}\text { Agar tidak mudah begeser } \\
\text { ketika pakaian APD dike- } \\
\text { nakan }\end{array}$ \\
\hline 4 & $\begin{array}{l}\text { Bagian } \\
\text { pinggang } \\
\text { belakang }\end{array}$ & $\begin{array}{l}\text { Fitting, berkenaan dengan } \\
\text { keenakan pakai. Pakaian } \\
\text { APD pada umumnya dib- } \\
\text { uat agak longgar sehingga } \\
\text { diperlukan penguat pada } \\
\text { bagian pinggang agar ti- } \\
\text { dak mudah bergeser. }\end{array}$ \\
\hline
\end{tabular}

Tabel penempatan karet pada pakaian APD

\section{d. Finishing}

Pada bagian penyelesaian akhir beberpa tindakan dalam pembuatan prototype ini diantaranya penyempurnaan ukuran, pembersihan dan pembuatan kemasan pakaian APD. Pada penyempurnaan ukuran dilakuakan uji pakai terkait dengan keenakan pakai dan ukuran. Ketika dilakukan uji pakai jika terdapat kekurangan maka dilakukan pembetulan. Sedangkan pada sisi lain pula dilakuakan pembuatan kemasan pakaian APD hal ini disamping untuk penampilan juga untuk menjaga kebersihan dari pakaian APD ini. Berikut ini gambar prototype pakaian APD hasil penelitian.

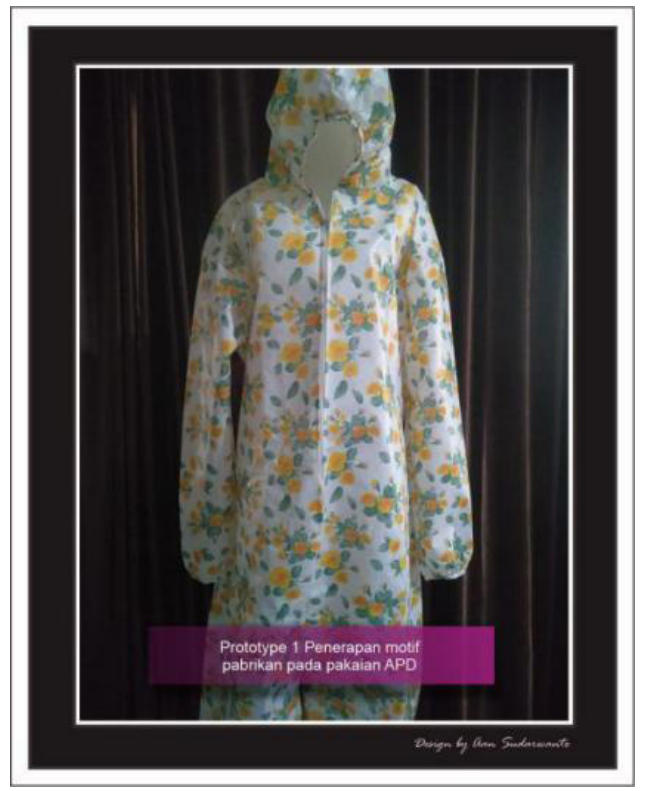

Gambar pakaian APD, prototype 1 hasil pengembangan penerapan Motif batik agar memunculkan kesan familier (Sudarwanto, 2020).

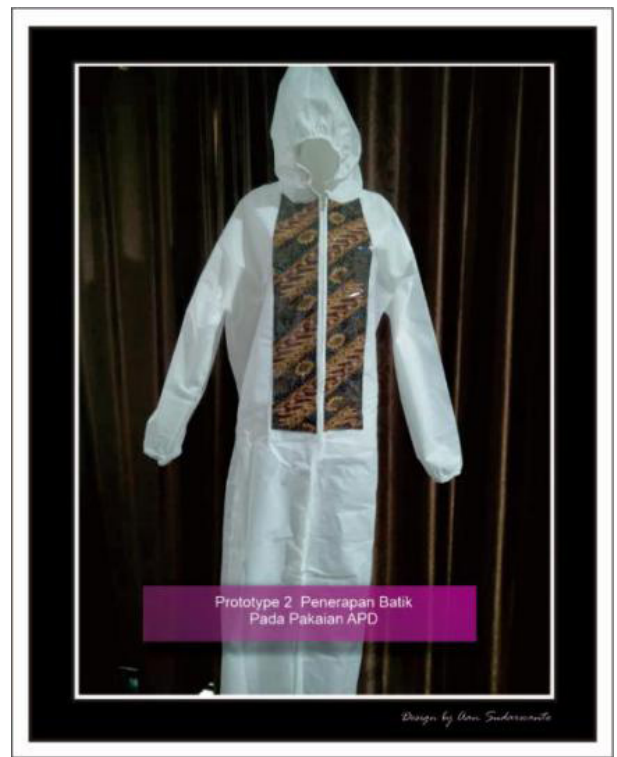

Gambar pakaian APD, prototype 2 hasil pengembangan penerapan Motif batik agar memunculkan kesan familier (Sudarwanto, 2020). 


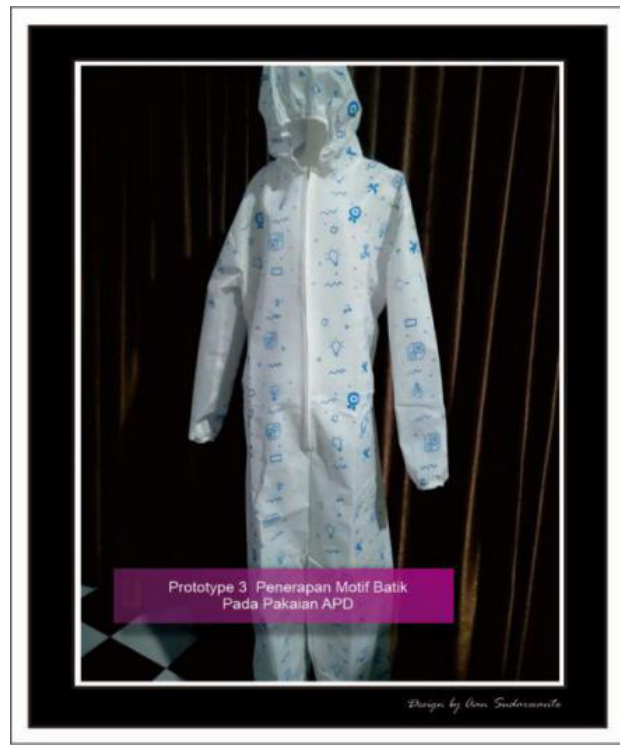

Gambar pakaian APD, prototype 3 hasil pengembangan penerapan Motif batik agar memunculkan kesan familier (Sudarwanto, 2020).

\section{KESIMPULAN}

Berpijak dari pembahasan yang telah diuraikan, dapat diambil kesimpulan bahwa penganekaragaman motif batik dapat digunakan sebagai penghias pada pakaian APD. Hal-hal yang perlu diperhatikan terkait hal tersebut antar lain, pemilihan material yang tepat karena terkait dengan standar kesehatan. Hasil penelitian ini menunjukkan, teknik penerapan motif batik pada pakaian APD dapat dilakukan dengan beberapa cara. Diantaranya teknik printing, selain itu juga bisa dengan teknik penambahan variasi batik dengan cara menempelan batik pada pakaian APD. Pada teknik yang kedua tersebut agar tetap memenuhi standar maka digunakan penutup plastik mika sehingga tetap waterproof.

Pengembangan model bentuk pakaian APD dengan varian motif batik sebagai penghias akan memberikan persepsi kesan familier. Selain itu juga akan memberi tambahan keindahan. Mengacu pada hasilhasil penelitian ini maka pengembangan pakaian APD dengan tambahan motif batik dapat dijadikan acuan para pelaku/ penggiat industri fasyen pada saat ini.

\section{DAFTAR PUSTAKA}

Ardyananta, Hosta., Widyastuti, Azzah Dyah Pramata, dan Diah Susanti, (2020). "Sedikit Banyak tentang Material APD dalam Penanganan Covid-19" Departemen Teknik Material dan Metalurgi., Teknologi Industri dan Rekayasa Sistem (FTIRS)

h t t p s: / / w w w . a y o b a ndung . com / $\mathrm{read} / 2020 / 04 / 09 / 85457 /$ polisi-wajib-pakai-apd-selama-pandemi-corona, diakses 22 April 2020

https://www.liputan6.com/health/read/4218517/ syarat-standar-alat-pelindung-diri-saattangani-corona-covid-19, diakses 21 April 2020

Sudarwanto, Aan. (2012). Batik dan Simbol Keagungan Raja. Surakarta. LPKBN Citra Sains.

Sudarwanto, Aan. (2019). Penerapan Model Bentuk Transformasi Menggunakan Teknik Karakter Terkuat untuk Menghasilkan Motif Batik., Tekstur Jurnal Seni \& Budaya Vol. 2 Nomor 1, 2019 